\begin{tabular}{|c|c|c|}
\hline & Klinikal Sains 7 (2) (2019) & \\
\hline & $\begin{array}{l}\text { JURNAL ANALIS KESEHATAN } \\
\text { KLINIKAL SAINS }\end{array}$ & 7 \\
\hline ABDURRAB & http://jurnal.univrab.ac.id/index.php/klinikal & 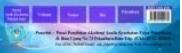 \\
\hline
\end{tabular}

\title{
SENYAWA METABOLIT SEKUNDER KULIT DUKU (lansium domesticum corr) SEBAGAI PENGHAMBAT PEMATANGAN TELUR ASCARIS LUMBRICOIDES
}

\author{
Darmadi, Suci Meilasari* \\ Program Studi DIII Analis Kesehatan, Fakultas Kedokteran dan Ilmu Kesehatan, Universitas Abdurrab \\ Jalan Riau Ujung No. 73 Pekanbaru \\ Telp (0761) 38762,839036 \\ Alamat e-mail: succimeiilasari98@gmail.com
}

\begin{tabular}{|c|}
\hline Info Artikel \\
\hline \begin{tabular}{l}
\multicolumn{1}{c}{ Sejarah Artikel: } \\
Diterima November 2019 \\
Disetujui November 2019 \\
Dipublikasikan \\
Desember 2019
\end{tabular} \\
\hline $\begin{array}{l}\text { Keywords: } \\
\text { Ascaris lumbricoides, } \\
\text { kulit duku (Lansium } \\
\text { domesticum Corr) }\end{array}$ \\
\hline
\end{tabular}

\begin{abstract}
Abstrak
Cacing Ascaris lumbricoides merupakan salah satu jenis cacing yang umum ditemukan pada anak sekolah. Penyakit kecacingan ini dapat mengakibatkan menurunnya kondisi kesehatan, gizi, kecerdasan dan produktifitas penderita. Upaya pengobatan terhadap Ascaris lumbricoides bisa di sembuhkan dengan insektisida alami yang berasal dari tumbuhan kulit buah duku, tujuan dari penelitian ini untuk mengetahui senyawa metabolit sekunder kulit duku terhadap pematangan telur Ascaris lumbrocoides. Penelitian ini menggunakan eksperimen laboratorium secara in vitro, adanya perlakuan yang di berikan pada objek penelitian dengan pemberian ekstrak kulit duku pada konsentrasi $(5 \%, 10 \%, 15 \%)$ pada konsentrasi $10 \%, 15 \%$ mampu melisiskan telur Ascaris lumbricoides dalam jangka waktu selama 1 jam. Senyawa metabolit sekunder yang terkandung di dalam ekstrak kulit duku adalah flavonoid dan triterpenoid.
\end{abstract}

Kata Kunci: Ascaris lumbricoides, kulit duku (Lansium domesticum Corr)

\begin{abstract}
Ascaris lumbricoides worms are a type of worm commonly found in school children. This worm disease can lead to a decrease in the condition of health, nutrition, intelligence and productivity of patients. Treatment efforts for ascaris lumbricoides can be cured with natural insecticides originating from the fruit skin of duku, the purpose of this study was to determine the secondary metabolite compounds of duku skin on the maturation of ascaris lumbrocoides eggs. This study used laboratory experiments in vitro, the treatment given on the object of research with the administration of duku skin extract at concentrations $(5 \%, 10 \%$, $15 \%)$ at a concentration of $10 \%, 15 \%$ were able to lyse the eggs of ascaris lumbricoides for a period of 1 hour. The secondary metabolite compounds contained in the extract of duku skin are flavonoids and triterpenoids.
\end{abstract}

(C) 2019 Universitas Abdurrab 


\begin{tabular}{lc}
\hline Alamat korespondensi: & ISSN 2338-4921 \\
Jalan Riau Ujung No.73 Pekanabaru & \\
E-mail: succimeiilasari98@mail.com &
\end{tabular}

\section{PENDAHULUAN}

Indonesia merupakan negara tropis yang masih banyak ditemukan berbagai macam jenis penyakit yang menjadi permasalahan dalam bidang kesehatan. Dari berbagai jenis penyakit tersebut infeksi cacing merupakan salah satu sebagai kontribusi penyebab infeksi helminth. Jenis cacing tersebut Ascaris lumbricoides (Safar, 2010).

Cacing Ascaris lumbricoides merupakan salah satu jenis cacing yang umum ditemukan pada anak sekolah. Penyakit kecacingan ini dapat mengakibatkan menurunnya kondisi kesehatan, gizi, kecerdasan dan produktifitas penderita (KEPMENKES RI No.424/2006). Berdasarkan hasil survei departemen kesehatan republik Indonesia beberapa Provinsi di Indonesia menunjukan bahwa prevalensi kecacingan semua umur di Indonesia berkisar antara 40-60\% (Resnhaleksmana, 2014).

Menurut Fessenden (2006) upaya pengobatan terhadap Ascaris lumbricoides bisa di sembuhkan dengan pemberian obat yang mengandung bahan kimia namun penggunaan produk-produk insektisida kimia tersebut dapat menimbulkan efek samping. Oleh sebab itu upaya yang dapat dilakukan mengurangi dampak negatif akibat penggunaan bahan kimia yang berlebih yaitu dengan menggunakan insektisida alami.

Insektisida alami merupakan bahan aktif yang berasal dari tumbuhan, relatif mudah dibuat dan tidak menimbulkan dampak negatif bagi manusia maupun lingkungan sekitarnya (Erviana, 2014). Salah satu tanaman yang memiliki potensi sebagai insektisida alami adalah kulit buah duku, hasil penelitian membuktikan bahwa kulit buah duku dapat bermanfaat sebagai insektisida alami.

Berdasarkan penelitian Fidiana (2013), menyatakan bahwa pemanfaatan ekstrak kulit buah duku (Lansium domesticum Corr) mampu sebagai anti nyamuk elektrik terhadap nyamuk Aedes aegypti. Senyawa yang terdapat pada kulit duku adalah flavonoid dan saponin.

Penelitian yang dilakukan oleh Wijayakusuma, (2000) bahwa daya anthelmintik infusa bawang putih terhadap cacing gelang (Ascaris suum) babi secara invitro mampu membunuh, sedangkan penelitian yang telah dilakukan oleh Ni'mah dkk (2015), menyatakan bahwa ekstrak biji buah duku juga berpotensi sebagai larvasida terhadap larva Aedes aegypti

Berdasarkan latar belakang yang telah diuraikan diatas maka penulis tertarik untuk melakukan penelitian dengan judul senyawa metabolit sekunder kulit duku (lansium domesticum corr) sebagai penghambat pematangan telur Ascaris lumbricoides. 


\section{METODE PENELITIAN}

Desain penelitian yang digunakan adalah eksperimen laboratorium secara in vitro. Populasi pada penelitian ini telur cacing Soil Transmitted Helminths (STH). Sampel yang digunakan dalam penelitian ini suspensi telur cacing Ascaris Lumbricoides.

Alat yang digunakan dalam penelitian ini ada kaca objek, kaca penutup, lidi, tabung reaksi, mikroskop, neraca analiti, oven, rotary evaporator, blender dan beberapa peralatan gelas lainnya yang dibutuhkan. Bahan yang di pergunakan dalam penelitian ini ada feses, eosin 2\%, kulit duku, metanol, akuades dan bahan kimia yang diperlukan lainnya.

\section{Prosedur Kerja}

\section{Identifikasi telur Ascaris lumbricoides}

Persiapkan kaca objek yang bersih dan bebas lemak, letakkan feses seujung lidi dan ditambahkan 1-2 tetes eosin $2 \%$ diatas kaca objek kemudian ditutup dengan kaca penutup pastikan agar sedian tipis dengan cara menekan kaca penutup lalu diperiksa di bawah mikroskop dengan perbesaran 100x ( Rahmadhini, 2016).

\section{Pengujian lisis telur Ascaris lumbricoides terhadap ekstrak kulit buah duku}

Pemeriksaan ini menggunakan kosentrasi yang bertingkat mulai 5\%,10\%,15\%, terlebih dahulu siapkan plate tetes diberi label sesuai kosentrasi yang diperiksa. Teteskan 10 tetes larutan ekstrak kulit duku kosentrasi 5\% pada plate tetes tersebut. Pada plate tetes ke II, 10 tetes larutan ekstrak kosentrasi 10\% pada objek glass III, 10 tetes larutan ekstrak kulit duku kosentrasi 15\%, dan tambahkan suspensi feses segar sebanyak 2 tetes pada plate tetes masing-masing kosentrasi. Amati dibawah mikroskop dengan lensa perbesaran10-40x. Terjadi lisis pada telur cacing Ascaris Lumbricoides dengan terlihat rusaknya komponen sel telur dengan pemberian ekstrak kulit duku (Lansium domesticum corr) pada kosentrasi tertentu.

\section{Analisis Data}

Data yang diperoleh dari hasil penelitian disajikan dalam bentuk tabel dan dianalisis secara deskriptif.

\section{HASIL DAN PEMBAHASAN}

Ekstrak kulit duku (Lansium domesticum corr) yang telah dibuat dilaboratorium, sebelum dilakukan pengujian pada uji lisis telur Ascaris lumbricoides, ekstrak kulit duku (Lansium domesticum 
corr) terlebih dahulu dilakukan uji fitokimia. Tujuannya adalah untuk mengetahui golongan senyawa kimia yang terdapat dalam ekstrak kulit duku( Lansium domesticum corr).

Tabel 1 Kandungan metabolit sekunder ekstrak kulit duku

\begin{tabular}{|c|c|c|}
\hline Senyawa & Hasil & Keterangan \\
\hline Flavonoid & $(+)$ & Terbentuk warna jingga \\
\hline Fenolik & $(-)$ & Tidak terbentuk warna ungu \\
\hline Saponin & $\begin{array}{l}(-) \\
(-)\end{array}$ & Tidak terbentuk busa \\
\hline Alkaloid & $(+)$ & Tidak terbentuk warna merah \\
\hline Triterpenoid & & Terbentuk warna jingga \\
\hline
\end{tabular}

Berdasarkan hasil uji fitokimia bahwa ekstrak kulit duku (Lansium domesticum corr) mengandung senyawa flavonoid, saponin, alkaloid, dan triterpenoid.

Uji Lisis Terhadap Ekstrak Kulit Duku. Berdasarkan hasil penelitian ekstrak kulit duku (Lansium domesticum corr) dengan menggukanan suspensi feses segar, maka diperoleh hasil sebagai berikut:

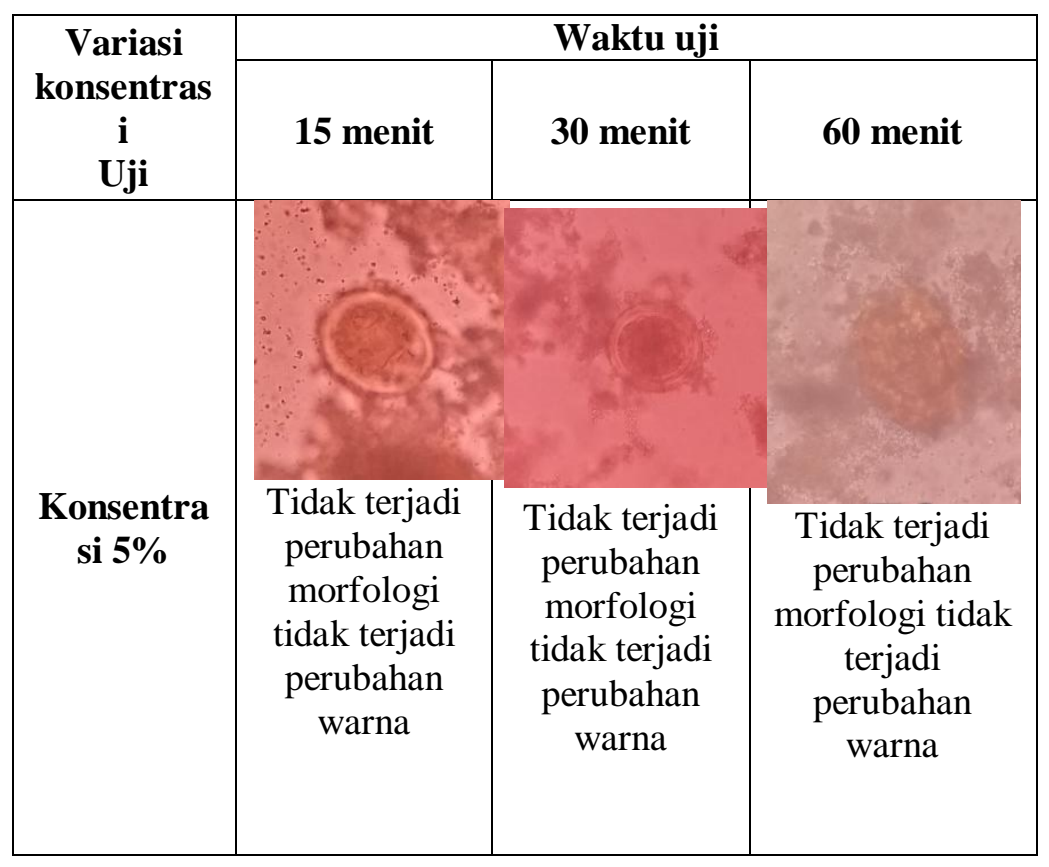




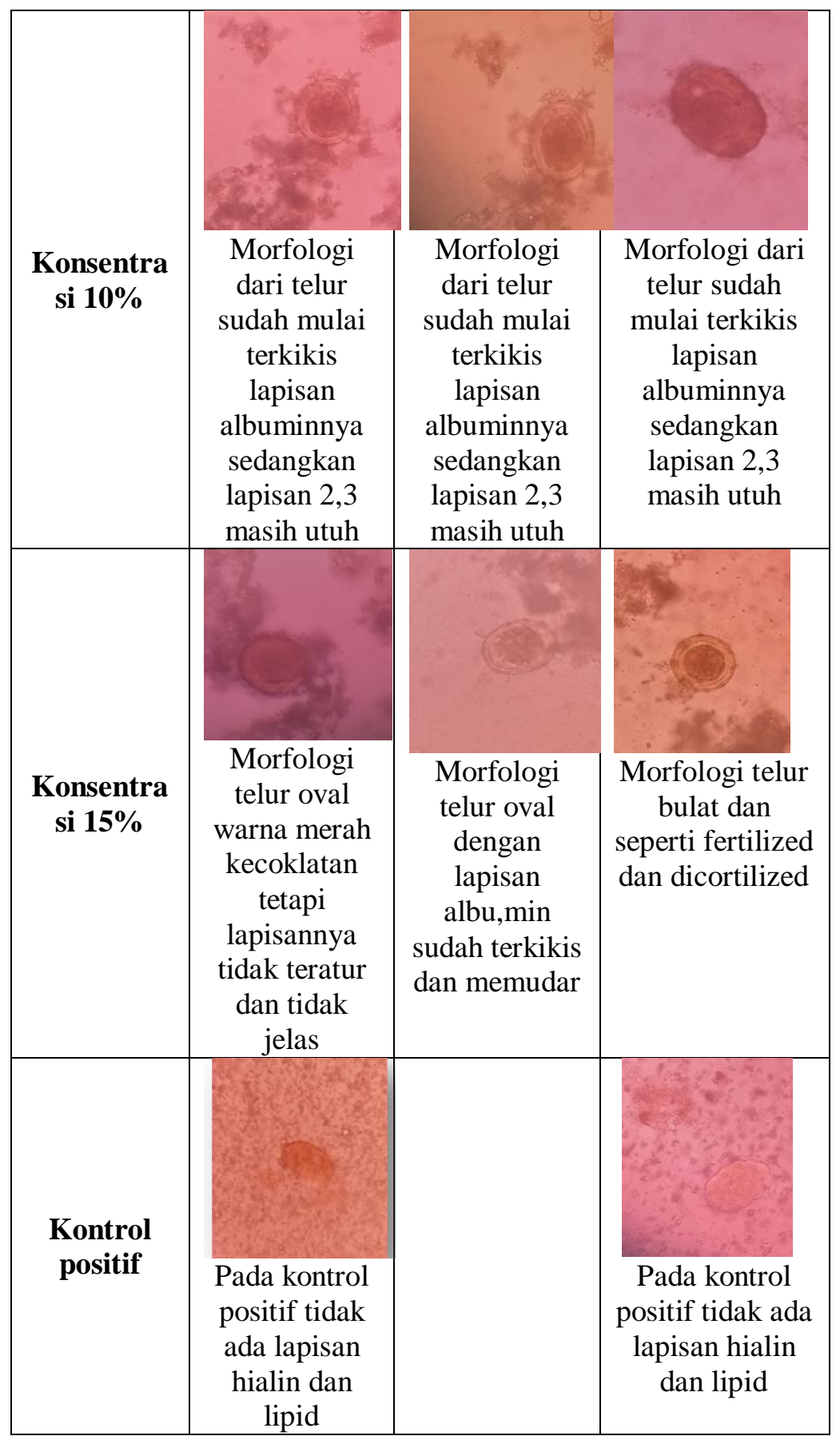




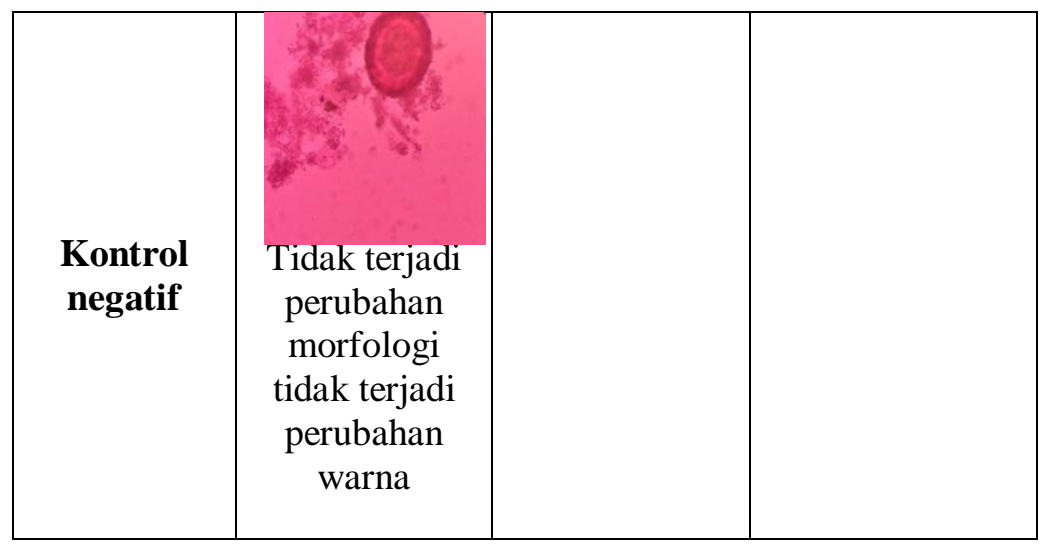

Berdasarkan hasil yang telah dilakukan bahwa ekstrak kulit duku (Lansium domesticum corr) mampu merubah morfologi telur Ascaris lumbricoides pada konsentrasi $10 \%$ dan 15\%, dari konsentrasi $5 \%, 10 \%$, dan $15 \%$. Perubahan morfologi telur terjadi setelah dilakukannya pengujian dari ekstrak kulit duku yang dilakukan dalam waktu 60 menit.

Pada kontrol positif dengan waktu yang sama, juga mampu merubah morfologi telur Ascaris lumbricoides. Berbeda dengan kontrol negatif yang tidak mengalami perubahan. Terjadinya perubahan morfologi pada lapisan telur berupa terkikisnya lapisan albumin yang terdapat pada Ascaris Lumbricoides. Dengan menggunakan kontrol positif, yang dilakukan dalam pengujian ini dapat merubah terjadinya lisis dengan menggunakan kontrol positif. Perubahan yang terjadi yaitu terkikisnya lapisan albumin dari telur Ascaris Lumbricoides tersebut.

Hasil uji fitokimia dengan menggunakan ekstrak kulit duku diperoleh senyawa fitokimia yaitu senyawa flavonoid yang ditandai dengan adanya perubahan warna jingga sampai merah, sedangkan senyawa triterpenoid ditandai dengan adanya perubahan warna sampai merah jingga. Senyawa metabolit sekunder yang terdapat didalam ekstrak kulit duku diantaranya flavonoid dan triterpenoid yang bertujuan untuk menghambat sintesa asam nukleat atau DNA (Taslim, 2007).

Terjadinya perubahan morfologi dari telur Ascaris Lumbricoides disebabkan kandungan senyawa metabolit sekunder yang terdapat dalam ekstrak kulit duku. Senyawa metabolit sekunder yang berpotensi merubah morfologi telur Ascaris Lumbricoides diantaranya senyawa flavonoid dan triterpenoid. Menurut (Fessenden, 2006) bahwa senyawa metabolit sekunder yaitu triterpenoid mempunyai aktivitas yang merusak membrane sel atau DNA, sedangkan menurut (Stephen, 2010) adanya senyawa flavonoid sebagai senyawa komplek dengan protein ekstraseluler yang terlarut sehingga dapat merusak membrane sel yang diikuti dengan keluarnya senyawa intraseluler, flavonoid merupakan senyawa fenol yang mempunyai kemampuan menggangu dinding sel, dan menurut (Arbiastutie,2008) triterpenoid adalah merupakan 
senyawa yang disintesis dari unit asetat yang mempunyai kemampuannya menggangu DNA, mekanisme senyawa triterpenoid sebagai penyebab rusaknya membrane sel.

Menurut (Stoker, 2010) flavonoid mampu menghambat sintesa asam nukleat, sebagai DNA diperlukan dalam sintesa atau pembentukan protein, yang sangat diperlukan untuk proses perkembangan dan pertumbuhannya. Jika sintesa DNA terhambat maka sintesa parotein akan terhambat pula sehingga perkembangan dan pertumbuhan tidak optimal bahkan nisa menyebabkan lapisan telur Ascaris Lumbricoides tersebut terkikis.

Menurut (Bethony, 2006) triterpenoid memiliki aktivitas untuk menghambat serta berinteraksi dengan lapisan telur Ascaris Lumbricoides yang kemudian akan merusak lapisan tersebut sehingga dapat merusak morfologi.

\section{KESIMPULAN}

1. Didapatkan ekstrak kulit duku ( Lansium domesticum corr) terdapat senyawa metabolit sekunder yaitu flavonoid,dan triterpenoid.

2. Bahwa ekstrak kulit duku (Lansium domesticum corr) berfungsi sebagai insektisida alami. Dengan konsentrasi $10 \%$ dan 15\% dapat merusak lapisan telur Ascaris lumbricoides dalam jangka waktu 1 jam.

\section{DAFTAR PUSTAKA}

Arbiastutie Y, Muflihati. (2008). Isolasi dan uji aktivitas kandungan kimia bioaktif dari biji duku (Lansium domesticum Corr). Jurnal Penelitian Universitas Tanjungpura. Volume X(2),70-86.

Budiyanti, R, T. 2010. Efek Antihelmintik Infus Herba Sambiloto (Andrographis paniculata, Nees) terhadap Ascaris suum secara in vitro. Skripsi. Fakultas Kedokteran. Universitas Sebelas Maret

Bethony J, Brooker S, Albonico M, Geiger SM, Loukas A, et al. Soil transmitted helminth infections: Ascariasis trichuriasis, and hookworm. Lancet. 2006; 367:1521-32.

Darmadi, Pradha, D., \& Setiawan, S. E. (2018). Efektifitas Ekstrak Kulit Duku (Lansium Domesticum Corr) Terhadap Mortalitas Pedikulus Humanus Capitis Sebagai Penyebab Pedikulosis Pada Anak. JOPS, I, 10-19.

Erviana, R dan Nukmal, N. 2014. Uji Potensi Kulit Buah Duku (Lansium domesticum) Terhadap Mortalitas Kecoa Amerika (Periplaneta americana) Dewasa. Bandar Lampung. FMIPA Universitas Lampung. Halaman $308-315$. 
Fidiana, D. F., Mifbakhuddin dan Nurullita, U. 2013. Daya Bunuh Ekstrak Kulit Duku (Lansium domesticum Corr.) Terhadap Kematian Larva Aedes aegypti. Jurnal Kesehatan Masyarakat Indonesia. 8 (2): Halaman 22-29.

Fessenden. 2006. Kimia Organik Jilid 2. Ed. 3..Erlangga. Jakarta

Frederick A B, William H, Brown, dkk. 2010. Introduction to general, organic, and biochemistry. Kanada : Nelson Education Ltd.

Irianto, k. 2009. Panduan Pratikum Parasitologi Dasar Untuk Paramedis Dan Nonmedi. Yrama. Widya. Bandung.

Istiqomah. (2013). Perbandingan Metode Ekstraksi Maserai Dan Sokletasi Terhadap Kadar Piperin Buah Cabe Jawa ( Piperis retrofraci fructus). Skripsi Jurusan FarmasiUIN Hidayatullah Jakarta.

Mayanti, T. 2009. Kandungan Kimia dan Bioaktivitas Tanaman Duku. Unpad Press. Bandung.

Natadisastra, D dan Ridad, A. 2009. Parasitologi Kedokteran. Penerbit EGC. Jakarta.

Ni’mah T, Oktarina R, Mahdalena V, Asyati D. (2014). Potensi ekstrak biji duku (Lansium domesticum Corr) terhadap Aedes aegypti. Buletin Penelitian Kesehatan.43(2),131-136.

Safar, R. 2010. Parasitologi Kedokteran Protozoologi, Entomologi dan Helmintologi. Yrama Widya. Bandung.

Surptiastuti, 2006. Infeksi Soil-Transmitted Helminth : Ascaris, Trichuriasis Dan Cacing Tambang Jurnal Kedokteran Universa Medicina. Fakultas Kedokteran Universitas Indonesia. Jakarta.

Sutanto, I., Ismid, I.S., Sjarifudi, P.K.,Sungkar, S. 2009. Buku Ajar Parasitologi Kedokteran: Kandidosis. Edisi 4. Jakarta: Fakultas Kedokteran Universitas Indonesia. Pp. 356-62

Stoker, H. Stephen. 2010. General, Organic, And Biological Chemistry Fifth Edition Page 684 . Cengage Learning. Belmont, CA USA 